\title{
Efficacy of Edible Chitosan Formulation in Quality Maintenance and Shelf Life of Guava (Psidium guajava L.) Fruit During Cold Storage
}

\author{
Amina $^{1}$, Muhammad Zahid Rashid ${ }^{1 *}$ and Amina Rashid ${ }^{2}$
}

${ }^{1}$ Horticultural Research Institute, Faisalabad; ${ }^{2}$ Department of Agronomy, University of Agriculture Faisalabad, Pakistan.

Abstract | Guava is crop of tropical and subtropical regions, but the consumption time is three or four days,
so it cannot be sold in a distant market. This trial was carried out to investigate the role of chitosan coating on
partially mature guava to retain good quality and prolong shelf life in cold $\left(11^{\circ} \mathrm{C}\right)$. Different chitosan concen-
trations i.e. $20 \% 30 \%$ and $40 \%$ were coated and stored at $11^{\circ} \mathrm{C}$ temperature. These fruits were compared with
control (non-treated) fruit after 15 days. It was observed that the fruits coated with $40 \%$ chitosan showed
minimum weight losses of $18.66 \%$ at cold storage $\left(11^{\circ} \mathrm{C}\right)$ respectively as compared to control where weight
losses were $34.50 \%$ at cold storage respectively. Treated fruits were firmer $(41.67 \mathrm{~N})$ after 15 days storage
period as compared to control. Fruit chilling injury percentage was also minimum at cold storage $(12.67 \%)$
in fruits coated with $40 \%$. All the treatments exhibited potential to maintain the post-harvest life of fruits as
compared to untreated fruits. These were found effective in quality attributes such as TSS, titratable acidity,
total sugars, total phenolic compounds as well as antioxidants.
Received $\mid$ February 21,$2018 ;$ Accepted | October 11,$2021 ;$ Published $\mid$ December 19,2021
*Correspondence $\mid$ Muhammad Zahid Rashid, Horticultural Research Institute, Faisalabad, Pakistan; Email: uafzahid@gmail.com
Citation | Amina., M.Z. Rashid and S. Rashid. 2021. Efficacy of edible chitosan formulation in quality maintenance and shelf life of guava
(Psidium guajava L.) fruit during cold storage. Sarbad Journal of Agriculture, 38(1): 266-274.
DOI $\mid$ https://dx.doi.org/10.17582/journal.sja/2022/38.1.266.274
Keywords | Guava, Chitosan, Coating, Cold storage

\section{Introduction}

G uava (Psidium guajava L.) has distinct status in Pakistan and ranked forth on the base of area 63,739 ha and 488,017 tons production. Soil and climate of Punjab and Sindh most suitable for guava production. Punjab is assuming crucial part in production of guava with 373007 tones from an area of 52,462 ha (Anonymous, 2015).

Guava is high nutritional because in light of the fact

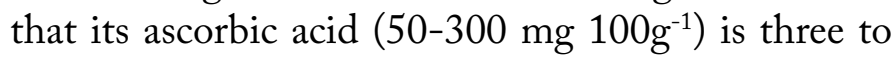
six times more as compare to citrus (Mercadante et al., 1999). Its pulp has great action as cancer prevention agent (Musa et al., 2010). But, harvested guava can show respiration ratio high and fast maturing which leads to delicate throughout storing period.
Guava fruit will certainly damage if preserved for three to five days in an ambient temperature (Kumar et al., 2012). A few methods are there to retain the guava fruit's value are; storage at low temperature, controlled atmosphere, the utilization of coating on fruit surface, and chemical material. The temperature throughout the storage significantly influences on fruit's physiology. Respiration rate works fast due to high temperature that will correspondingly accelerate the fruit loss. Low temperature storage expects to reduce respiration, minimize the attack of microorganism and transpiration. Cold temperature storage is a viable and proficient effort since it will reduce respiration through limiting enzyme reaction.

Chitosan is get from prawn shell remaining which has truly great intensity as fruit surface covering 
agent. Earlier literature demonstrate that chitosan has qualities to shape film, antimicrobial, and decomposable (Bourtoom et al., 2008).

Furthermore, chitosan has high potential as an edible and decomposable coating in food stuff packaging (Arvanitoyannis et al., 1998), has tremendous biocompatibility, non-toxicity (Jayakumar et al., 2005; Prabaharan et al., 2005) and also has layer making and blockade qualities (Arvanitoyannis et al., 1998), which makes it possible for eatable layer. Past studies described that chitosan covering enhance the storage of various delicate fruits, for example longan (Kaur et al., 2017), peach (Li et al., 2001) and grapes (Romanazzi et al., 2002). Moreover, various examinations have evidently demonstrated that chitosan can be utilized as a successful additive to enhance the quality and time span of usability of different fruits (Meng et al., 2008). So, main purpose of this study was to evaluate prospective impact of chitosan treatments on shelf life of guava cultivar 'Gola' and quality aspects in cold storage.

\section{Materials and Methods}

\section{Fruit material}

Guava Cv. 'Gola' were picked from an orchard of Horticultural Research institute and Post Harvest Research center AARI, Faisalabad during year 20182019. Uniform fruit were separated and selected for research.

\section{Preparation of chitosan formulation}

Chitosan solutions were made with the method of Jiang et al. (2001). To make the $500 \mathrm{ml}$ of $0,20 \%$, $30 \%$ and $40 \%(\mathrm{w} / \mathrm{v})$ chitosan solution, exact weight of $0,100,150$ and $200 \mathrm{~g}$ of chitosan was added in $50 \mathrm{ml}$ of glacial acetic acid correspondingly, before $400 \mathrm{ml}$ of double distilled water was added to dissolve more chitosan. The $\mathrm{pH}$ maintained at 6.0 with $1 \mathrm{M} \mathrm{NaOH}$ and the solution prepared up to $500 \mathrm{ml}$.

\section{Treatments}

Fruit dipped into different solutions of 0 (control), $20 \%, 30 \%$ and $40 \%$ chitosan for 1 minute, respectively. Fruits kept for 30 minutes at ambient temperature and put into plastic bags and all bags having five fruits with 10 bags each group, and then kept for cold storage $\left(11^{\circ} \mathrm{C}\right)$ with $90-95 \%$ relative humidity.

All evaluations were showed with three replications.
After storage fruits were continuously examined visually on daily basis to observe the changes in appearance. After 4 weeks of storage the fruits were analyzed on following parameters.

\section{Measurement of fruit color, Firmness, weight loss and chilling injury}

Fruit color was carefully examined of each fruit in all replications using horticultural chart and scoring was allocated to each fruit the average was computed. Firmness was measured by Penetrometer and then average was calculated. Weight loss was calculated by formula: $(A-B) / A \times 100$, there $A$ is the before storage fruit weight and $B$ is the after cold storage fruit weight.

Chilling injury and fruit rotting were noted according to treatments. Daily basis fruit rotting occurrence was noted and chilling injury incidence was recorded after 7 days. Rotted fruits were discarded from store and percentage was considered on 4 weeks after storage.

Measurement of Total Soluble Solids, Titratable Acidity, Ascorbic Acid, Total Sugars, Reducing sugar, Non Reducing Sugars, Total Phenolic compounds and Antioxidants

TSS of juice was estimated via digital refractometer (Atago-Palette PR101, Tokyo, Japan). To conclude titratable acidity, fruit juice titrated against $0.1 \mathrm{M}$ $\mathrm{NaOH}$ solution and results were provided in percentage. Vitamin $\mathrm{C}$ of juice was calculated by method of Ruck (1969) and unit mentioned as mg $100 \mathrm{ml}^{-1}$.

1. Total sugars, reducing and non-reducing sugars were determined by Lane and Eynon method as defined by Ranganna (2008).

2. Total phenolic contents were determined through Folin-Ciocalteu reagent and absobance read at $765 \mathrm{~nm}$ using method Singleton et al. (1999).

3. Total antioxidants were determined by $50 \mu \mathrm{lex}-$ tract was added into $5 \mathrm{ml} 0.004 \%(4 \mathrm{mg} / 100 \mathrm{ml})$ of methanol solution of DPPH. Afterward for 30 mints kept in incubation at room temperature and afterward absorbance was estimated at $517 \mathrm{~nm}$.

Research was designed according to completely randomized design along with three replications. Each treatment contained ten fruits. Data was evaluated statistically by Statistix software. Analysis of variance technique was used to check total significance of data whereas to relate the difference among treatment 
means applied least significance difference (LSD) test.

\section{Results and Discussion}

Fruit color

Regarding fruits stored in cold storage $\left(11^{\circ} \mathrm{C}\right)$ after 15 days most color retained with $40 \%\left(\mathrm{~T}_{3}\right)$ having an average score color of 1.38. Control $\left(\mathrm{T}_{0}\right)$ and $20 \%$ chitosan $\left(\mathrm{T}_{1}\right)$ showed most changes in color tending towards yellow by average score of 2.47 and 2.51 after 15 days respectively.

Coatings are utilized as a semi permeable boundary to delay colour loss and browning by enzymatic reaction or drying out which are a piece of the cutting procedure reaction (Prabaharan et al., 2006). Though, no significant difference was found about color change amongst control and treated strawberry fruits applying various concentrations of chitosan (Rocha et al., 2007). In past investigation, it was discovered that $\mathrm{pa}^{-}$ paya coated with chitosan showed maximum color in the storage duration (Gonzalez-Aguilar et al., 2009) (Figure 1).

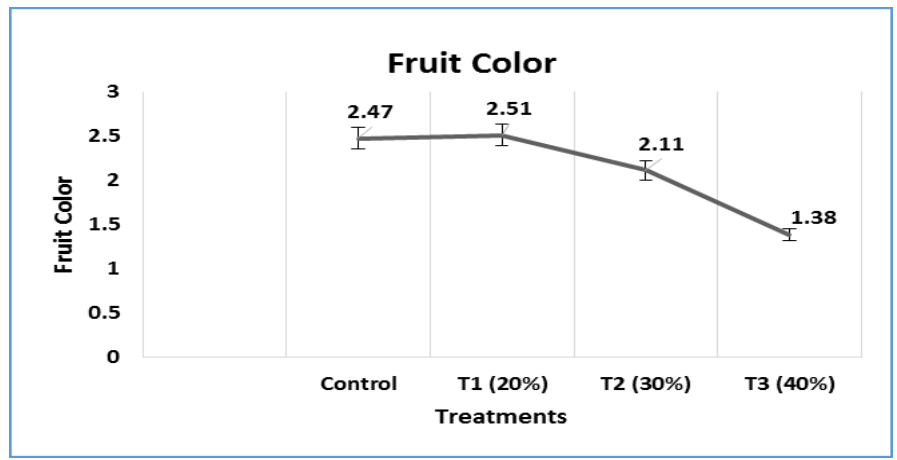

Figure 1: Effect of Chitosan coatings on fruit color of guava.

Fruit weight loss (\%)

Chitosan reduced the weight loss percentage which was recorded significantly low $18.66 \%$ in $40 \%$ and significantly high $(34.00 \%)$ in control and treated fruits (Figure 2).

Chitosan coating evidently a obstacle for surface evaporation; consequently, a reduced weight reduction in coated fruit.

These results are in line with earlier worker Krishna and Rao (2014) where the loss of weight of the guava fruit can be lessened by covering it with chitosan. In addition to guava fruit, chitosan coating has been compelling in adjusting reduction of weight of differ- ent crops, including longan fruit. Jiang et al. (2001) and strawberry fruit (Gonzalez-Aguilar et al., 2009). The loss in weight of fresh horticultural crops is mostly due to transpirational water loss (Zhu et al., 2008) (Figure 2).

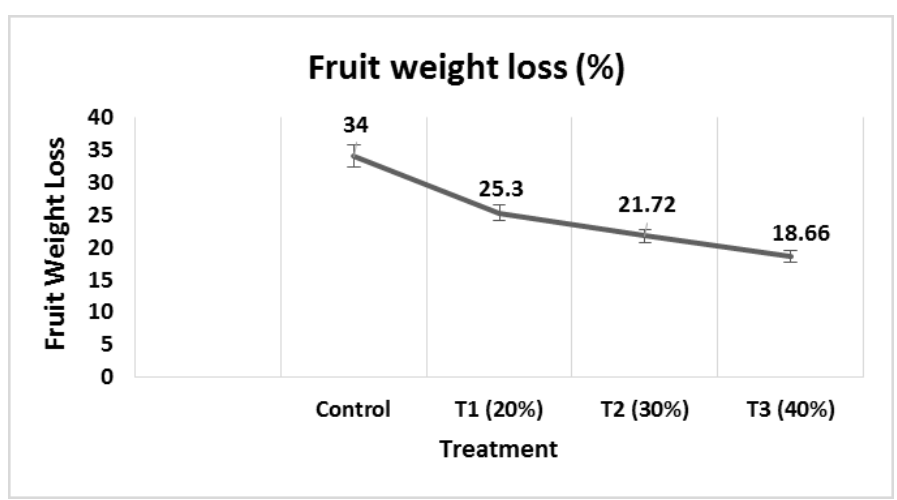

Figure 2: Effect of chitosan coating on weight loss (\%) of guava.

\section{Fruit firmness}

The fruit firmness is a vital morphological factor to examine the ripening progress. The fruits treated with chitosan $40 \%$ recorded maximum firmer fruits (6.67 $\mathrm{N})$ after 15 days, while in control it was minimum $(3.88 \mathrm{~N})$. Cold storage condition revealed slow rate of loss of fruit firmness. The present findings are in accordance with work of Krishna and Rao (2014) in guava fruits. Results of firmness retaining results are corresponding to the earlier worker (Ali et al., 2011) who described that $2.0 \%$ chitosan coating on papaya retained the firmness than other treatments at low temperature storage $\left(11^{\circ} \mathrm{C}\right)$.

In our experiment, with increasing the chitosan concentrations fruit softening was lessened and subsequently, treated fruit with control and $20 \%$ chitosan vanished their textural integrity quicker as compare to fruit treated with 30 and $40 \mathrm{mg}$ chitosan.

Fruit softening occurs due to cell structure disintegration, the cell wall structure and ingredients (Scanavaca et al., 2007). Firmness of guava can be conserved due to fruit treated with chitosan that have high antifungal action and layer of the lenticels and cuticle, along these decreasing contamination, respiration and further maturing developments during storage, as indicated by past research on sweet cherry and papaya treated with chitosan and aloe vera gel (Scanavaca et al., 2007; Seymour, et al., 1993) (Figure 3).

Chilling injury percentage was recorded subsequently 15 days of cold storage $\left(11^{\circ} \mathrm{C}\right)$. Figure 4 revealed March 2022 | Volume 38 | Issue 1 | Page 268 
that fruits coated with $40 \%$ and $30 \%$ chitosan stored at cold storage $\left(11^{\circ} \mathrm{C}\right)$ had less chilling injuries. Both had $12.67 \%$ and $13.33 \%$ decay after 15 days of storage respectively. Maximum chilling injuries were observed in control treatment (T0) which showed 30\% of chilling injuries. Our findings were supported by earlier workers on papaya (Gonzalez-Aguilar et al., 2009) and litchi (Dong et al., 2004).

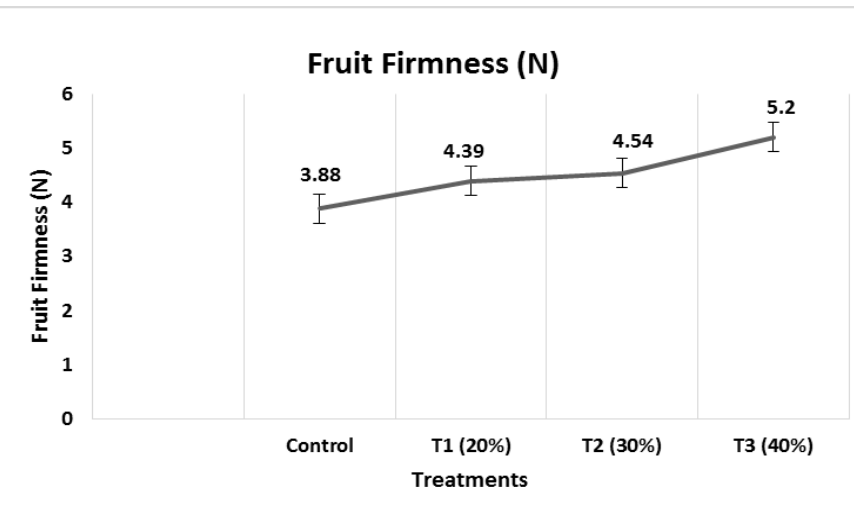

Figure 3: Effect of chitosan coating on fruit firmness of guavaChilling Injury.

In this study, browning of control and $20 \%$ chitosan coated samples limited restrict the time span of usability in term of visual quality. These browning can results because of dehydration or microbial contamination or activity of PPO enzymes that are unregulated by the cutting procedure and oxidize phenols into quinines within the sight of sub-atomic oxygen. Sliced mango quality and prolonged shelf life or peeled litchi fruit were also described to be due to the chitosan coating forming film and protect the fruit surface (Dong et al., 2004).

Correspondingly, in this work, the increasing and adequate amount of $40 \%$ chitosan on guava improved its quality and prevented decay development. The current study showed that the resistance of the surface to contamination can be achieved by the coating to delay contamination (Figure 4).

\section{Total soluble solids}

Total soluble solids was also influenced significantly with days of storage conditions and treatments. As for as fruits coated with chitosan and stored at cold temperature after 15 days are concern total soluble solid of fruits coated with T2 chitosan (30\%) had maximum total soluble solids of $8.33^{\circ}$ Brix followed by T3 (40\%) which showed $8.00{ }^{\circ}$ Brix (Figure 4 and 2). $\mathrm{T} 1(20 \%)$ revealed non-significant results with control (T0) by showing $5.80{ }^{\circ}$ Brix after 15 days of storage.
Consequences of this study are very close with results of earlier workers (Yueming et al., 2005). During fruit ripening TSS increased because activity of enzymes improved and these enzymes do hydrolysis of starch to sugars (Hernández-Munoz et al., 2008) (Figure 5).

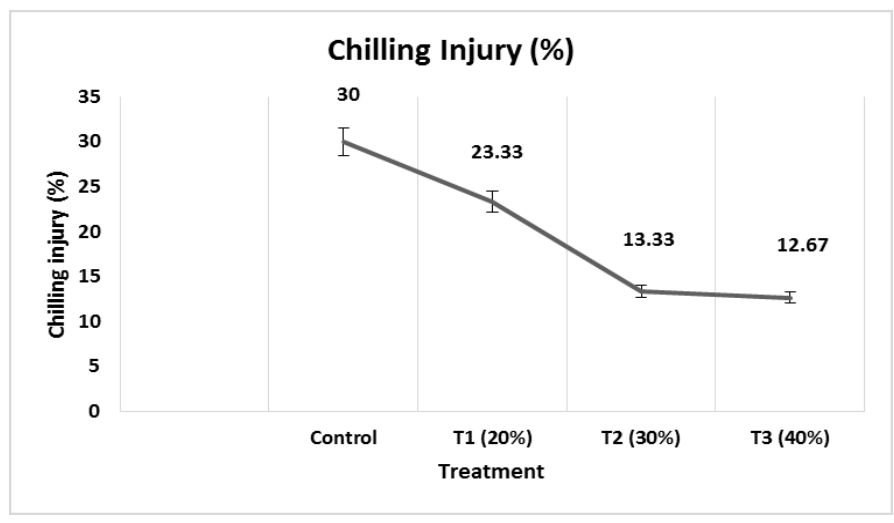

Figure 4: Effect of chitosan coating on fruit chilling injury of guava.

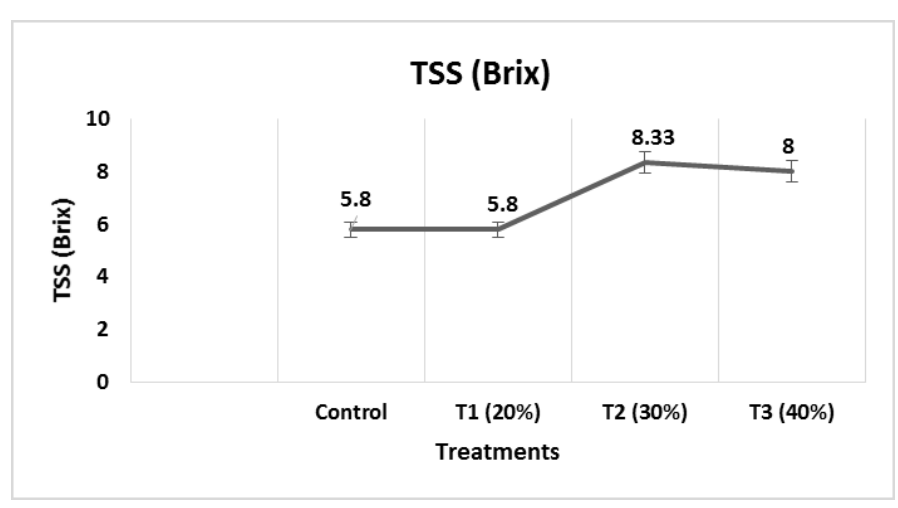

Figure 5: Effect of chitosan coatings on total soluble solids of guava. Titratable acidity.

Titratable acidity was gradually reduced all treatments throughout the storage period (Figure 6). Maximum total titratable acidity was observed in T3 (40\%) which showed $0.30 \%$ total titratable acidity while $\mathrm{T} 1$ showed intermediate value $0.28 \%$. Least aggregate titratable acidity was seen by applying T0 (control) which gave $0.24 \%$ total titratable acidity following 15 days of storage. Hong et al. (2012) described that during storage in guava chitosan coated fruit has lower acidity loss and may take part to delay the fruit senescence. Our findings showed similarities with the study of earlier worker (Nongtaodum et al., 2009) who observed titratable acidity decreased in coated fruits as compared to control.

Retention of titratable acidity has been described for different fruits preserved with edible coatings (Ali et al., 2011; Yaman et al., 2012). 
Ascorbic acid

Maximum fruit ascorbic acid $(231.60 \mathrm{mg} / 100 \mathrm{~g})$ was recorded in chitosan $40 \mathrm{mg}$ (T3) which was statistically at par with T2 $(217.27 \mathrm{mg} / 100 \mathrm{~g})$ and T1 $(215.00$ $\mathrm{mg} / 100 \mathrm{~g})$ while minimum $(197.80 \mathrm{mg} / 100 \mathrm{~g})$ was recorded in control (T0) after 15 days of storage respectively.

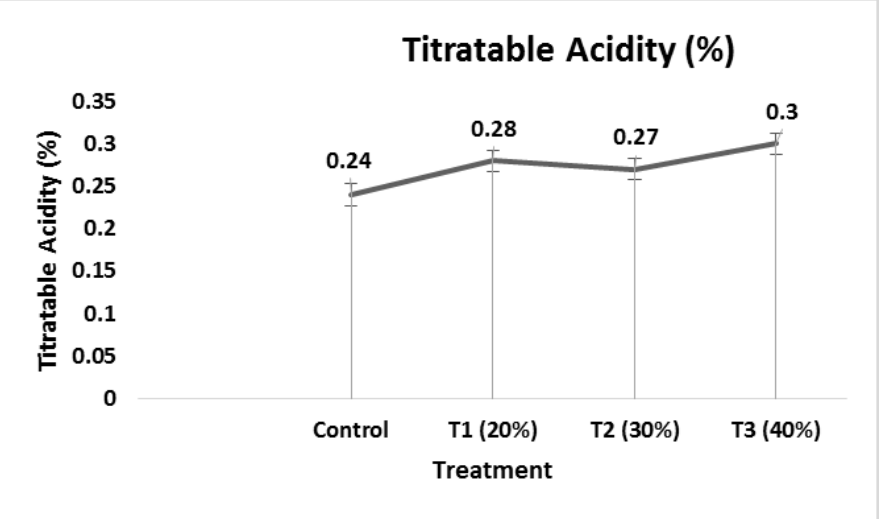

Figure 6: Effect of chitosan coatings on titerable acidity of guava.

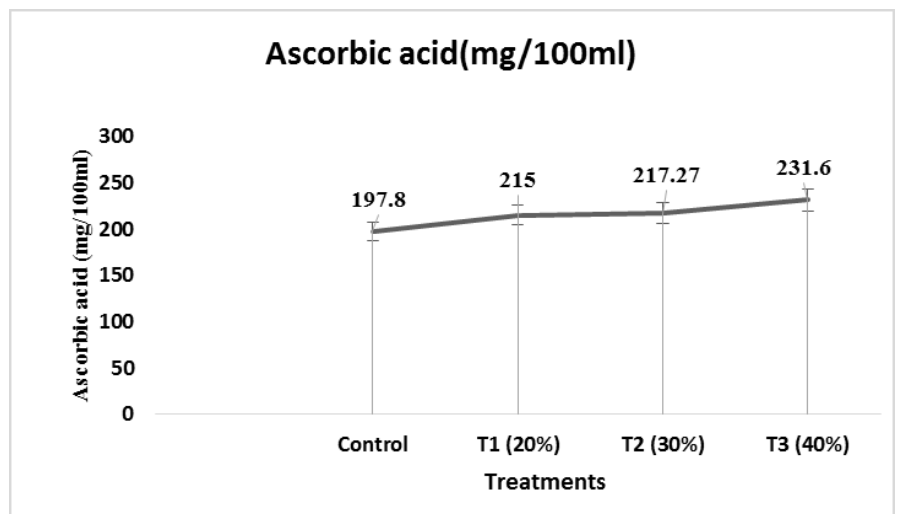

Figure 7: Effect of chitosan coatings on Ascorbic acid of Guava.

Fruit surface pores concealed due to various concentrations of chitosan, so crossing of oxygen is controlled (Zhang et al., 1997). Thus, the oxidizing of ascorbic acid may be effected (Wahab et al., 2012). Results of our study are close with the findings of earlier workers (Trung et al., 2011; Ali et al., 2011). They observed that chitosan treated fruits showed high value of ascorbic acid (Figure 7).

\section{Total sugars}

The total sugars of the guava fruits increases till the end of the storage duration except untreated fruits under cold storage condition. The maximum mean total sugars $(6.97 \%)$ were recorded in (T0) control after 15 days of storage. Minimum total sugar percentage was recorded in (T3) $40 \%$ having $6.6 \%$. Total sugar content increases may be because alteration of starch into sugars. Kaur et al. (2017) noted that total sugars increased (6.43\%) with chitosan application $(1.5 \%)$. But results are in contrast with findings of earlier worker (Trung et al., 2011) who reported that total sugars were decreased in apple (Figure 8).

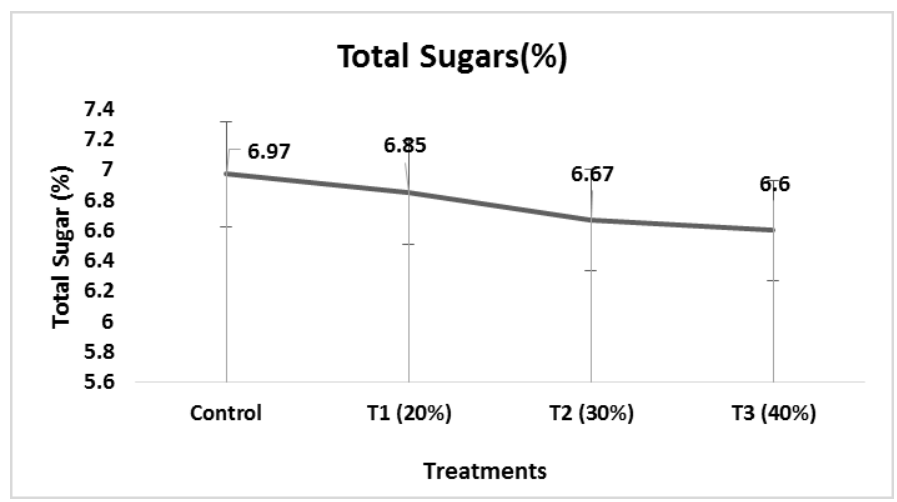

Figure 8: Effect of chitosan coatings on Total sugars (\%) of Guava.

Reducing sugars were recorded after 15 days of cold storage $\left(11^{\circ} \mathrm{C}\right)$. Figure 9 showed the data about the correlation of average reducing sugar with the four various intensities of chitosan.

Maximum reducing sugars $3.82 \%$ was noted in Fruits treated with $40 \%$ chitosan (T3) showed maximum reducing sugars $3.82 \%$, followed by $30 \%$ (T2) which showed $3.79 \%$ reducing sugar. Minimum reducing sugar percentages were recorded for $20 \%$ chitosan (T1) and control (T0) by having $3.57 \%$ and $3.48 \%$ reducing sugars after 15 days of storage respectively. During the storage reducing sugar increases possibly due to the enzymatic alteration of starch to reducing sugar.

Finding of present study were in support of findings of earlier worker (Chailoo et al., 2008) who observed that coated sweet cherries had increased reducing sugar percentage. This view concurs to the findings of Abbasi et al. (2009) observed that the postharvest nature of mango fruit effected by chitosan coating and also detected that the total sugar, reducing sugar and non-reducing sugar contents were less in the coated samples (Figure 9).

\section{Non reducing sugars}

Figure 10 give the data regarding assessment of non reducing sugars via the applications of four various level of chitosan. Maximum non-reducing sugars 3.49 $\%$ was seen in control (T0) after 15 days of storage subsequently, 30\% (T2) which presented $3.28 \%$ nonreducing sugars. After 15 days of storage $2.78 \%$ minimum non reducing sugar was recorded in T3 (40\%). 


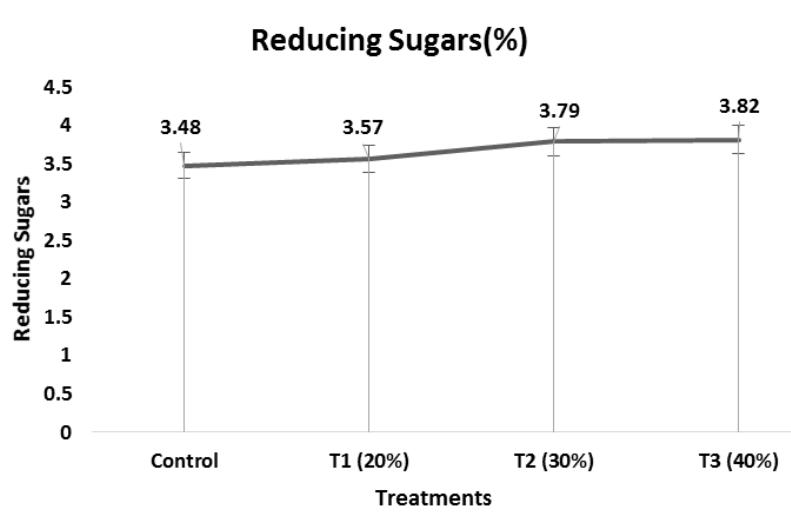

Figure 9: Effect of chitosan coatings on Reducing sugars of Guava. Reducing sugars

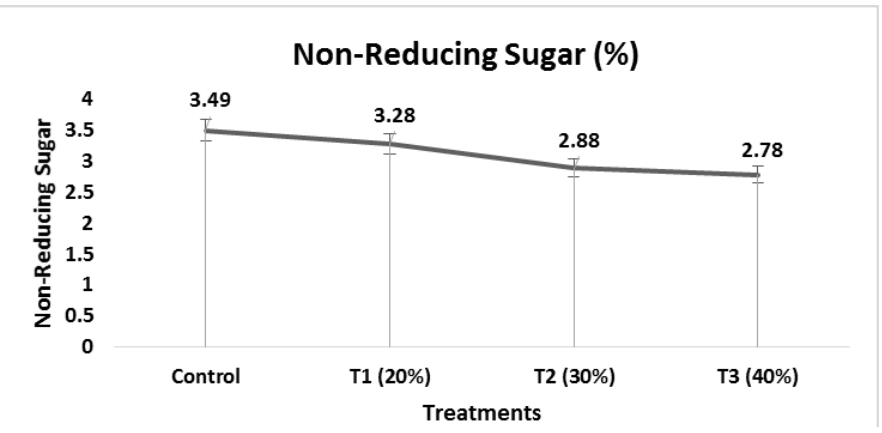

Figure 10: Effect of chitosan coatings on Non Reducing Sugars of Guava.

Our findings were parallel to the consequences of Hoa and Ducamp (2008) on 'cat Hoa loc' mango where they observed the impact of various coatings and perceived that contents of total sugar, reducing sugar and non-reducing sugar were minimum in the coated fruit. Our findings are in close with earlier worker (Ali et al., 2011).

\section{Total phenolic compounds}

Phenolic compounds has high biological activity in cancer and heart diseases anticipation (Rocha et al., 2007). Treatments exerted a significant influence on total phenolic compounds (Figure 4 and 11). Highest phenolic compounds was noted in fruits treated with $40 \%$ chitosan having $340.67 \mathrm{mg} \mathrm{GAE} / \mathrm{ml}$ after 15 days of storage and as well also $30 \%$ chitosan (T2) which indicated $325.67 \mathrm{mg}$ GAE/ml phenolic compounds. T2 and T3 both indicated similar results. $20 \%$ chitosan (T1) and control (T0) vary non-significantly by having $318.67 \mathrm{mg} \mathrm{GAE} / \mathrm{ml}$ and $300.67 \mathrm{mg}$ $\mathrm{GAE} / \mathrm{ml}$ phenolic compounds respectively.

Our results are in contrast as compare to findings of earlier workers (Sanchez et al., 2011) in grapes. They found that phenolic compounds increased with chitosan coatings in grapes.
Total Phenolic Compunds (mg GAE/ml )

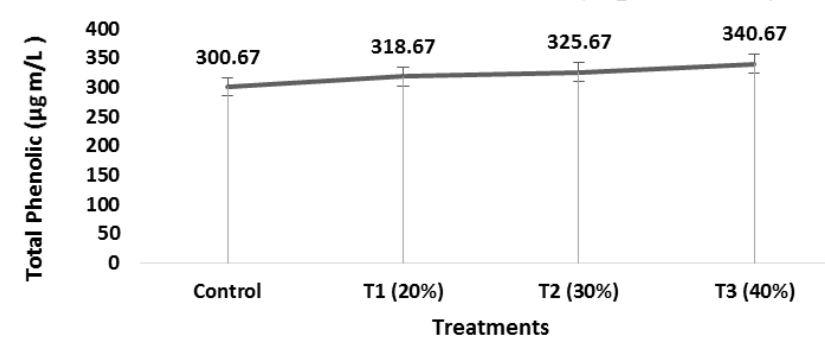

Figure 11: Effect of chitosan coatings on Total Phenolic Compounds of Guava.

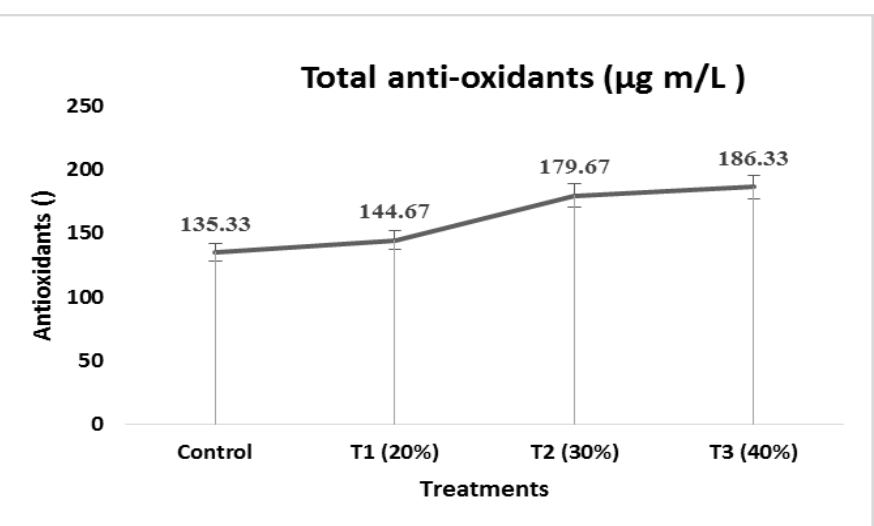

Figure 12: Effect of chitosan coatings on total antioxidents of guava.

Total anti-oxidants

Total anti-oxidants were recorded after 15 days of cold storage $\left(11^{\circ} \mathrm{C}\right)$. Figure 12 revealed that maximum anti-oxidants $186.33 \mu \mathrm{g} / \mathrm{ml}$ were in $40 \%$ chitosan (T3) treated fruits followed by $30 \%$ chitosan (T2) that revealed $179.67 \mu \mathrm{g} / \mathrm{ml}$ anti-oxidants. Control (T0) having anti-oxidants $135.33 \mu \mathrm{g} / \mathrm{ml}$ and vary non-significantly from each other after 15 days of storage. Same findings were found in grapes (Sanchez et al., 2011).

\section{Conclusions and Recommendations}

Chitosan coating, particularly $40 \%$ chitosan coating combined with a cold storage conditions $\left(11{ }^{\circ} \mathrm{C}\right)$ slow down the fruit maturity and as well as retained the quality of the guava fruit. The results proposed that chitosan demonstrated encouraging effect in keeping membrane integrity and reduction in oxidative stress mostly delayed maturity development in guava fruit.

\section{Acknowledgments}

The authors acknowledge the Post Harvest Research center, AARI Faisalabad (Pakistan) to facilitate regarding equipment. 


\section{Novelty Statement}

Our research work evidently demonstrated that chitosan can be utilized as a successful additive to enhance the quality and time span of usability of different fruits. Moreover, main purpose of this study was to evaluate prospective impact of chitosan treatments on shelf life of guava cultivar 'Go-la' and quality aspects in cold storage. It has no side effect on human health and a unique product for commercial purpose.

\section{Author's Contribution}

Amina: Wrote the manuscript.

Muhammad Zahid Rashid: Performed laboratory work and statistical analysis.

Amina Rashid: Removed the plagiarism in manuscript and performed bio-chemical analysis .

\section{Conflict of interest}

The authors have declared no conflict of interest.

\section{References}

Abbasi, N., Z. Iqbal, M. Maqbool and I. Hafiz. 2009. Postharvest quality of mango (Mangifera indica L.) fruit as affected by chitosan coating. Pak. J. Bot., 41. 343-357.

Ali, A. Muhammad, M.T.M.K. Sijam and A.R.M. Zaki. 2005. Effect of chitosan coating on the retention of colour development and firmness of papaya fruit during storage. In: Proceedings of First International Symposium on Papaya, 22-24 November, Genting Highlands, Malaysia.

Ali, A. Muhammad, M.T.M.K. Sijam and Siddiqui, Y. 2011. Effect of chitosan coatings on the physicochemical characteristics of Eksotika II papaya (Carica papaya L.) fruit during cold storage. Food Chem., 124: 620-626. https:// doi.org/10.1016/j.foodchem.2010.06.085

Anonymous. 2015. Fruits, vegetables and condiments of Pakistan. Government of Pakistan, Ministry of Food, Agriculture and livestock (Economics Wing), Islamabad.

Arvanitoyannis, I.S. 1999. Totally and partially biodegradable polymer blends based on natural and synthetic macromolecules: preparation, physical properties, and potential as food packaging materials. J. Macromol. Sci. Rev. Mac- romol. Chem. Phys., 39: 205-271. https://doi. org/10.1081/MC-100101420

Arvanitoyannis, I.S.,A. Nakayama and S. Aib. 1998. Chitosan and gelatin based edible films: state diagrams, mechanical and permeation properties. Carbohydr. Polym., 37: 371-382. https:// doi.org/10.1016/S0144-8617(98)00083-6

Bourtoom, T. 2008. Edible films and coatings: Characteristics and properties. Int. Food Res. J. 15 (3): 237-248.

Chailoo, M.J. and M.R. Asghri. 2011. Hot water and chitosan treatment for the control of postharvest decay in sweet cherry (Prunus avium L.) cv. Napoleon (Napolyon). J. Stored Prod. Postharv. Res., 2(7): 135-138.

Dong, H., L. Cheng, J. Tan, K. Zheng and Y. Jiang. 2004. Effects of chitosan coating on quality and shelf life of peeled fruit. J. Food Eng., 64. 355358.10.1016/j.jfoodeng.2003.11.003.

Gonzalez-Aguilar, G.A., E. Valenzuela-Soto, J. Lizardi-Mendoza, F. Goycoolea, M.A. Martinez-Tellez., M.A. Villegas-Ochoa, I.N. Monroy-Garcia and J.F. Ayala-Zavala. 2009. Effect of chitosan coating in preventing deterioration and preserving the quality of fresh-cut papaya 'Maradol'.J. Sci. Food Agric., 89: 15-23. https:// doi.org/10.1002/jsfa.3405

Hernández-Munoz, A.E., V.D. Valle, D. Velez and R. Gavara. 2008. Effect of chitosan coating combined with postharvest calcium treatment on strawberry (Fragaria $\times$ ananassa) quality during refrigerated storage. Food Chem., 110: 428-435. https://doi.org/10.1016/j.foodchem.2008.02.020

Hoa, T.T. and Ducamp, M. 2008. Effects of different coatings on biochemical changes of 'cat Hoa loc' mangoes in storage. Postharvest Biol. Technol., 48: 150-152. https://doi.org/10.1016/j. postharvbio.2007.09.021

Hong, K., Xie, J., Zhang, L., Sun, D. and Gong, D. 2012. Effects of chitosan coating on postharvest life and quality of guava (Psidium guajava L.) fruit during cold storage. Sci. Hort., 144: 172- 178. https://doi.org/10.1016/j.scienta.2012.07.002

Jayakumar, R., M. Prabaharan, R.L. Reis and J.F. Mano. 2005. Graft copolymerized chitosan - present status and applications. Carbohydr. Polym., 62: 142-158. https://doi.org/10.1016/j. carbpol.2005.07.017

Jiang, Y.M. and Y.B. Li. 2001. Effects of chitosan 
coating on postharvest life and quality of longan fruit. Food Chem., 73: 139-143. https:// doi.org/10.1016/S0308-8146(00)00246-6

Kaur, A., Gautam, R., Srivastava, R., Chandel, A., Kumar, A., Karthikeyan, S. and Bachhawat, A.K, 2017. $\mathrm{ChaC}_{2}$, an Enzyme for Slow Turnover of Cytosolic Glutathione. J. Biol. Chem., 292(2): 638-651. https://doi. org/10.1074/jbc.M116.727479

Krishna, K.R. and Rao, D.V.S. 2014. Effect of chitosan coating on the physiochemical Response of Guava Fruits to Post Harvest Treatments characteristics of guava (Psidium guajava L.) fruits during storage at room temperature. Indian J. Sci. Tech., 7: 554-58. https://doi. org/10.17485/ijst/2014/v7i5.4

Kumar, S.V., Lucyshyn, D., Jaeger, K.E., Alós, E., Alvey, E., Harberd, N.P. and Wigge, P.A., 2012. Transcription factor PIF4 controls the thermo sensory activation of flowering. Nature, 484: 242-245. https://doi.org/10.1038/nature10928

Li,H.andT.Yu.2001.Effect of chitosan on incidence of brown rot, quality and physiological attributes of postharvest peach fruit. J. Sci. Food Agric., 81: 269-274. https://doi.org/10.1002/1097$0010(20010115) 81: 2<269:$ :AID - J S FA806>3.0.CO;2-F

Meng, X., B. Li, J. Liu and S. Tian. 2008. Physiological responses and quality attributes of table grape fruit to chitosan preharvest spray and postharvest coating during storage. Food Chem., 106: 501-508. https://doi.org/10.1016/j.foodchem.2007.06.012

Mercadante, A.Z., Steck, A. and Pfander, H. 1999. Carotenoids from guava (Psidium guajava L.): isolation and structure elucidation. J. Agric. Food Chem., 47: 145-151. https://doi. org/10.1021/jf980405r

Musa, K.H., Abdullah, A. and Jusoh, K. 2010. Antioxidant activity of pink-flesh guava (Psidium guajava L.): Effect of extraction techniques and solvents. Food Anal. Meth., 4 (1): 100-107. https://doi.org/10.1007/s12161-010-9139-3

Nongtaodum, S. and A. Jangchud. 2009. Effects of edible coating on quality of fresh cut mangoes (Fa-lun) during storage. J. Net. Sci., 39: 300307.

Prabaharan, M. and J.F. Mano. 2006. Chitosan derivatives bearing cyclodextrin cavities as novel adsorbent matrices. Carbohydr. Polym., 63: 153-166. https://doi.org/10.1016/j.carb- pol.2005.08.051

Rangana, S. 2008. Hand book of analysis and quality control for fruit and vegetable products. 2 nd ed. New Delhi: Tata McGraw Hill Pub. Co. Ltd.

Ribeiro, C., A.A. Vicente, J.A. Teixeira and C. Miranda. 2007. Optimization of edible coating composition to retard strawberry fruit senescence. Postharvest Biol. Technol., 44: 63-70. https://doi.org/10.1016/j.postharvbio.2006.11.015

Rocha R.S., Queiroz, J., Lopes R.Q.M., Campos, F. and Pinheiro Sant'Ana, H. 2007. Antioxidant in mango (Mangifera indica L.) pulp. Plant Foods Human Nutr., 62: 13-17. https:// doi.org/10.1007/s11130-006-0035-3

Romanazzi, G., F. Nigro, A. Ippolito and M. Salerno. 2002. Effect of short hypobaric treatments on postharvest rots of sweet cherries, strawberries and table grapes. Postharv. Biol. Techno., 22:1-6

Ruck, J.A. 1969. Chemical Methods for Analysis of Fruits and Vegetables. Research Station Summerland, Canada Department of Agriculture. Publication No. 1154.

Sanchez, G.L., Pastor, C., Vargas, M., Chiralt, A., Gonzalez, M.C. and Chafer, M. 2011. Effect of hydroxy propyl methylcellulose and chitosan coatings with and without bergamot essential oil on quality and Safety of Cold-Stored Grapes. Postharvest Biol. Technol. Amsterdam, 60: 1: 57-63. https://doi.org/10.1016/j.postharvbio.2010.11.004

Sanchez-González, C. Pastor, M. Vargas, A. Chiralt and C. Gonzalez-Martinez. 2011. Effect of hydroxyl propyl methylcellulose and chitosan coatings with and without bergamot essential oil on quality and safety of cold-stored grapes. Postharvest Biol. Technol., 60: 57-6. https:// doi.org/10.1016/j.postharvbio.2010.11.004

Scanavaca, J.L, N. Fonseca and M.E.C. Pereira. 2007. Uso de fecula de mandioca na pos colheita de manga 'Surpresa'. Revista Brasileira de Fruticultura, 29: 067-071. https://doi. org/10.1590/S0100-29452007000100015

Seymour, G.B., J.E. Taylor and G.A. Tucker. 1993. Biochemistry of Fruit Ripening. Chapman and Hall Publishing, London, pp. 1-454. https:// doi.org/10.1007/978-94-011-1584-1

Singleton, V.L., Orthofer, R. and Lamuela-Raventons, R.M. 1999. Analysis of total phenols and 
other oxidation substrates and antioxidants by means of Folin Ciocalteu reagent. Methods Enzymol., 299: 152-178. https://doi.org/10.1016/ S0076-6879(99)99017-1

Siomos, A.S., D. Gerasopoulos, P. Tsouvaltzis, and A. Koukounaras. 2010. Effects of heat treatment on atmospheric composition and color of peeled white asparagus in modified atmosphere packaging. Innovative Food Sci. Emerg. Technol. 11: 118-122. https://doi.org/10.1016/j.ifset.2009.08.008

Srinivasa, P., R. Baskaran, M. Ramesh, K.H. Prashanth and R. Tharanthan. 2002. Storage studies of mango packed using biodegradable chitosan film. Eur. Food Res. Technol. 215(6): 504-508. https://doi.org/10.1007/s00217-0020591-1

Trung, T.S., N.T.H. Phuong and W.F. Stevens. 2011. Protective effect of chitosan coating and polyethylene film wrapping on post-harvest storage of sugar apples. As. J. Food Ag-lnd. 4(02): 81-90.

Wahab, S.M.A. and Rashid, I.A.S. 2012. Safe postharvest treatments for controlling Penicillium molds and its impact maintaining Navel Orange fruits quality. Am.Eu. J. Agric. Environ. Sci. 12 (7): 973-982.

Yaman, O. and Bayindirli, L. 2002. Effects of an edible coating and cold storage on shelf-life and quality of cherries. Lebensm-Wiss Technol., 35: 146. https://doi.org/10.1006/fst1.2001.0827

Yueming, J., L. Jianrong and J. Weibo. 2005. Effect of chitosan coating on shelf life of cold stored litchi fruit at ambient temperature. Lebensm. Wiss. Technol., 38(7): 757-761. https://doi. org/10.1016/j.lwt.2004.09.004

Zhang, D. and P.C. Quantick. 1998. Antifungal effects of chitosan coating on fresh strawberries and raspberries during storage. J. Hort. Sci. Biotech., 73:763-767. https://doi.org/10.1080/14 620316.1998.11511045

Zhu, X., Q.M. Wang, J.K. Cao, W.B. Jiang. 2008. Effects of chitosan coating on postharvest quality of mango (Mangifera indica L.CV. Tainong) fruits. J. Food Process. Preserv. 32, 770-784. https://doi.org/10.1111/j.17454549.2008.00213.x 